\title{
Effect of Substitution of Chicken Egg with Duck Egg on Biscuit Quality
}

\author{
F.M. Makinde ${ }^{1^{*}}$, K.D. Awoyera ${ }^{2}$, A.O. Oguntunji ${ }^{3}$ \\ 1,2Department of Food Science and Technology, Bowen University, Iwo, Osun State, Nigeria \\ ${ }^{3}$ Department of Animal Science and Fisheries Management, \\ Bowen University, Iwo, Osun State, Nigeria \\ *sademakin@yahoo.com
}

Keywords: Biscuit, eggs, nutrition, cholesterol, quality.

\begin{abstract}
Eggs are characterized with other components such antioxidants, folic acid and other B vitamins, and unsaturated fats which might have beneficial effects on heart disease risk that counterbalance the small adverse effect of the eggs' cholesterol content. A specific study of the effect of chicken egg and/or duck egg in biscuit production has allowed the determination of their respective effects on baking, chemical and sensorial properties. Five sample blends of chicken and duck eggs were made respectively from the following ratios: 0, 10:90, 20:80, 30:70, 40:60 and 50:50\%, respectively. Baking and nutritional properties of samples of biscuit were determined by standard methods, while sensory evaluation was also carried out. The results on the biscuit samples revealed the following ranges: baking properties (weight $14.53-14.85 \mathrm{~g}$, diameter $48.4-50.04 \mathrm{~mm}$, thickness $9.37-9.46 \mathrm{~mm}$, bulk density 0.61 to $0.82 \mathrm{~g} / \mathrm{cm}^{3}$ and spread ratio $5.12-5.37$; proximate parameters (moisture 3.22-4.78\%, ash $0.64-1.74 \%$, fibre $0.49-0.51 \%$, protein $9.4-12.9 \%$, fat $15.8-19.2 \%$, carbohydrate $62.4-68.8 \%$ and energy $397.67-411.85 \mathrm{kcal} / \mathrm{g}$ ). Biscuit samples contained varying amounts of calcium, phosphorus, potassium, magnesium, zinc and iron. Baking properties showed a decrease in the weight and thickness but increase in diameter and spread ratio of the biscuits with rising levels of substitution. The chemical analysis results revealed that biscuit samples containing different levels of duck egg had significantly higher fat, ash and protein content but lower moisture and carbohydrate than the control. Mineral concentration was significantly affected $(p \leq 0.05)$ by the substitution with duck egg in the biscuit formulations. The substitution of chicken egg with duck egg at a level of up to $40 \%$ produces biscuit without any negative effect in quality attributes and reasonable acceptance. Conclusively, the substitution of chicken egg with duck egg in biscuit production is an ideal approach to utilizing uncommon food ingredients. The use of duck egg produced biscuit with different characteristics and quality, depending on level of inclusion in the formulation, offering nutritious and healthy alternative to consumers.
\end{abstract}

\section{Introduction}

Biscuits are one of the confectionary food product consumed in Nigeria. They are ready to eat, nutritive snacks produced from unpalatable dough that is transformed into appetizing product through the application of heat in the oven [1]. They are convenient and inexpensive food product containing digestive and dietary properties of vital importance [2]. The principal ingredients are flour, fat, sugar and water; while other ingredients include milk, egg, salt and aerating agent [3]. The importance of egg is mainly due to the fact it has unique ability to form a cohesive gluten network in the dough in the presence of water. Beaten egg white is used, like baking powder, to give the dough light, airy texture. This is achieved because egg white (albumin) contains lecithin, a protein which lines the outside of the air bubbles created when the egg was beaten and so prevents them from collapsing during baking.

Egg could be produced from different breeds of chicken, duck, roe, and caviar; however by a wide margin the egg most often humanly consumed is the chicken egg, typically unfertilized [4]. Duck produces egg of larger size and more nutrients than chicken. It contains higher proportions of protein and dry matter comparatively [5]. The previous study also reported that duck eggs are packed with vitamins and minerals even with their bigger size, their nutritional value is three to four times 
greater than chicken eggs [6]. Regular consumption of duck eggs leaves human body more alkaline which is a great benefit to cancer patients as cancer cells do not thrive in an alkaline environment unlike chicken eggs which makes body more acidic [7]. The effectiveness of chemotherapeutic agents adopted in cancer treatment is markedly influenced by $\mathrm{pH}$. Death of cell correlates with acidosis and higher shifts in intracellular $\mathrm{pH}$ (more alkaline) after chemotherapy may reflect a response to chemotherapy [8]. However, there is no scientific literature establishing the benefit of an alkaline diet for the prevention of cancer at this time.

However, there is continued less utilization of duck eggs in food formulation solely because the yolk contains more cholesterol than chicken eggs. Surprisingly, consumers are only just beginning to understand the real effects of eating fat in daily diet. In practice, healthy active people who exercise need fat in their diet; otherwise their bodies would generate the cholesterol itself. Several recent studies have assessed the relationship between intake of eggs and/or dietary cholesterol and blood cholesterol levels or heart disease risk in free-living groups of people. In a study of more than 20,000 male smokers in Finland, no association was found between dietary cholesterol intake and the risk of death from heart disease over a six-year period [9]. This study is of special interest because the cholesterol intakes of the study participants were higher than those usually seen in United States studies. No relationship between egg intake and heart disease risk in these studies because eggs are characterized with other components such as antioxidants, folic acid and other B vitamins, and unsaturated fats which might have beneficial effects on heart disease risk that counterbalance the small adverse effect of the eggs' cholesterol content [10]. Furthermore, the American Heart Association dietary guidelines for healthy people no longer include a specific limitation on the number of eggs or egg yolks that a person may consume in a week [11]. Duck egg is an important source of high-quality protein in the diets of rural people whose traditional foods are typically rich in carbohydrate but low in protein.

The vexed question of the cholesterol content of eggs and human health seems to have been over exaggerated. The aim of this research is to examine the effect of substitution of chicken egg with duck egg on the physical, nutritional and sensorial qualities of biscuit.

\section{Materials and Methods}

\section{Procurement of raw materials}

Fresh indigenous duck egg and chicken egg used for this study were purchased from Animal Research Farm, Bowen University. Wheat flour and baking ingredients such as salt, sugar, baking powder, and margarine were purchased from Odo-Ori market in Iwo, Osun state. All the chemicals used in this analysis were of analytical grade.

\section{Experimental plan}

Table 1 shows the different combination of duck egg and chicken egg for biscuit preparation and the various ingredients are presented in Table 2.

\section{Production of biscuit}

Biscuits were produced from the blends using the method described by Onabanjo [12]. All the ingredients were weighed accurately. The pre-weighed flour, sugar, salt and baking powder were mixed thoroughly. The shortening (margarine) and beaten egg were added to the mixture and mixed until the uniform smooth dough was obtained. The dough was then transferred to a clean tray and gently rolled using a roller. The dough sheath was cut into round shapes using a cutter. Shaped dough pieces were placed into a greased pan, kept at a normal room temperature for $2 \mathrm{hr}$ to allow proper dough leavening and baked in a preheated laboratory oven operating at $217^{\circ} \mathrm{C}$ for $12 \mathrm{~min}$. After baking the biscuits were allowed to cool and packed in high-density polyethylene film and stored at room temperature for subsequent analyses. The biscuit samples produced from $100 \%$ chicken egg served as control. 
Table 1. Different combination of duck egg and chicken for biscuit production

\begin{tabular}{|c|c|c|}
\hline Treatment & Chicken egg (\%) & Duck egg (\%) \\
\hline T-0 & 100 & - \\
\hline T-1 & 90 & 10 \\
\hline T-2 & 80 & 20 \\
\hline T-3 & 70 & 30 \\
\hline T-4 & 60 & 40 \\
\hline T-5 & 50 & 50 \\
\hline
\end{tabular}

Table 2. Laboratory formulations of raw materials used in the preparation of biscuits $(\mathrm{g})$

\begin{tabular}{|l|l|l|l|l|l|l|l|l|}
\hline Treatment & Wheat & Sugar & Shortening & $\begin{array}{l}\text { Baking } \\
\text { powder }\end{array}$ & Salt & Water & $\begin{array}{l}\text { Chicken } \\
\text { egg }\end{array}$ & $\begin{array}{l}\text { Duck } \\
\text { egg }\end{array}$ \\
\hline T-0 & 100 & 30 & 20 & 2.5 & 0.5 & 115 & 30 & - \\
\hline T-1 & 100 & 30 & 20 & 2.5 & 0.5 & 113 & 27 & 3 \\
\hline T-2 & 100 & 30 & 20 & 2.5 & 0.5 & 111 & 24 & 6 \\
\hline T-3 & 100 & 30 & 20 & 2.5 & 0.5 & 110 & 21 & 9 \\
\hline T-4 & 100 & 30 & 20 & 2.5 & 0.5 & 109 & 18 & 12 \\
\hline T-5 & 100 & 30 & 20 & 2.5 & 0.5 & 108 & 15 & 15 \\
\hline
\end{tabular}

\section{Determination of baking properties}

Baking properties of the biscuit samples were determined according to AACC [13] methods.

\section{Weight}

The weight of three biscuits from each sample was determined on an electronic weighing balance (Mettler, Germany) and average recorded in grams (g). The analysis was carried out in triplicate.

\section{Diameter}

The diameter of biscuit samples was determined using a vernier calliper with zero error. Three well- formed biscuit samples from each sample were arranged edge to edge and their diameter was determined and the average was taken and recorded in millimetre $(\mathrm{mm})$. The analysis was carried out in triplicate.

\section{Thickness}

The thickness of the biscuit samples was measured using a micrometer screw gauge (zero error). Thickness was measured by stacking three well-formed biscuits on top of one another, then restacking in a different order and measuring them to get the average in millimetres. The analysis was carried out in triplicate.

\section{Spread ratio}

The spread ratio of the biscuit samples was determined by dividing the average value of the diameter by average value of thickness of same biscuit samples.

\section{Bulk density}

The bulk density was determined using the method as described by Okaka and Potter [14]. The biscuit sample was milled (Wiley mill, 30 mesh). A known weight of milled biscuit sample was poured into a clean and dry measuring cylinder. The measuring cylinder containing the milled biscuit sample was tapped slightly several times and stopped when there was no further reduction in volume of milled biscuit. The final volume was recorded and bulk density $\left(\mathrm{g} / \mathrm{cm}^{3}\right)$ was calculated using the formula below:

$$
\text { Bulk density }=\frac{\text { Weight of milled sample before tapping }}{\text { Volume of milled sample after tapping }}
$$




\section{Determination of chemical composition}

The proximate composition (moisture, protein, fat, ash and fiber) of different flour and biscuit samples were determined using standard procedures [15]. Carbohydrate content was determined by difference. The energy value was estimated $(\mathrm{kcal} / \mathrm{g})$ by multiplying the percentage crude protein, crude lipid and carbohydrate by the recommended factor $(2.44,8.37$ and 3.57 respectively) as described by Ekanayake et al. [16]. All analyses were carried out in triplicate.

\section{Determination of mineral composition}

Analysis of potassium content of the samples was carried out using flame photometry AOAC [17]. Phosphorus content was determined by the phosphomolybdate method [17]. The other elemental contents $(\mathrm{Ca}, \mathrm{Mg}, \mathrm{Fe}$ and $\mathrm{Zn})$ were determined, after wet digestion of sample ash with an atomic absorption spectrophotometer (Hitachi Z6100, Tokyo, Japan). All the determinations were carried out in triplicates.

\section{Sensory evaluation}

Sensory evaluation of biscuit samples from various blends was conducted using untrained 25member panel. The panel comprised a broad cross section of adult population (students and staff) of the Bowen University, with panellists spread across a wide range of age, education and income groups. Biscuit samples were prepared a day ahead of sensory evaluation and stored at room temperature. Samples were served in a randomized order on a tray, with portable water and spit cup for rinsing mouth in between tasting of samples to minimize rating errors, due to carry over of perceived attributes of previous sample. The panellists were asked to evaluate each sample based on the following parameters of colour, taste, flavour, texture, crunchiness, sweetness and overall quality using a 5-point Hedonic scale (5- like extremely and 1- dislike extremely) as described by Onwuka [18].

\section{Data analysis}

Data obtained were statistically analyzed using a one-way analysis of variance (ANOVA) and means were separated by Duncan's New Multiple Range Test (DNMRT) using the Statistical Package for Social Sciences (SPSS) version 17. Significance was accepted at 0.05 probability level.

\section{Results and Discussion}

\section{Baking quality of biscuit samples}

The biscuit quality parameters are given in Table 3 . The weight and diameter of the biscuit samples ranged between 14.53-14.85g and 48.40-50.40mm respectively. Biscuit weight was found to be decreasing by the substitution of chicken egg with duck egg. Higher fat content in duck egg compared to chicken egg contributes to a reduction in weight of biscuit which is then characterized by a friable structure. The diameter of biscuit samples increased with the inclusion of duck egg compared to the control (sample T-0). It has been reported that duck egg contains more fat than chicken egg [19]. Consequently, recipes with different levels of duck egg (samples T-1, T-2, T-3, T4 and T-5) required little water to produce cohesive and soft dough. During mixing, the fat coats the flour particles and this inhibits hydration and interrupts gluten formation. The low dough viscosity results in high flow rate (spread rate) of the dough and contributes to large diameter of biscuit samples containing duck egg in their formulation.

Thickness was significantly different among the biscuit samples. Substitution of chicken egg with duck egg negatively affected the thickness of biscuit. The decrease in the thickness of biscuit sample containing a varying proportion of chicken egg and duck egg was due to the dilution of gluten. Higher fat content noted in samples containing duck egg brought about decrease in dough viscosity and subsequent decrease in thickness [20]. The bulk density of the snack samples ranged from 0.61$0.82 \mathrm{~g} / \mathrm{cm}^{3}$ with samples T-3 and T-5 having the highest value, while sample T-0 had the least. Bulk density is a reflection of the load the samples can carry if allowed to rest directly on each other and the attribute is very important in determining raw material handling and packaging requirement [21]. By calculating the ratio between the diameter and the thickness of the biscuits, a significant increase 
$(p \leq 0.05)$ was recorded as the level of substitution of chicken egg with duck egg and increased. The low spread ratio value of sample T-0 showed that starch polymer molecules in wheat flour are highly bound with the granules and swelling is limited when heated. On cooling, the starch rapidly forms a rigid gel with capacity characteristics of large molecular aggregates [22]. However, substitution of chicken egg with duck egg containing more protein affects the rheological properties of the dough and its subsequent finished products. The increase in spread ratio is an indication of poor cohesion of the network of the protein and carbohydrates which are the principal nutrients in the products. The poor cohesion could allow the outflow of some ingredients such as sugar that could melt at the high temperature of baking hence increasing the spreadability of the material [23]. In earlier study, Hoseney and Roger [24] also reported that dough with lower viscosity causes cookies to spread at a faster rate.

Table 3. Baking properties of biscuit samples

\begin{tabular}{|l|l|l|l|l|l|}
\hline Sample & Weight $\mathbf{( g )}$ & $\begin{array}{l}\text { Diameter } \\
(\mathbf{m m})\end{array}$ & $\begin{array}{l}\text { Thickness } \\
(\mathbf{m m})\end{array}$ & $\begin{array}{l}\text { Spread } \\
\text { Ratio }\end{array}$ & $\begin{array}{l}\text { Bulk density } \\
\left(\mathbf{g} / \mathbf{c m}^{\mathbf{3}}\right)\end{array}$ \\
\hline T-0 & $14.85^{\mathrm{e}} \pm 0.05$ & $48.40^{\mathrm{a}} \pm 0.01^{\mathrm{a}}$ & $9.46^{\mathrm{d}} \pm 0.05$ & $5.12^{\mathrm{a}} \pm 0.02$ & $0.61^{\mathrm{a}} \pm 0.02$ \\
\hline T-1 & $14.72^{\mathrm{d}} \pm 0.01$ & $49.00^{\mathrm{b}} \pm 0.02^{\mathrm{b}}$ & $9.42^{\mathrm{c}} \pm 0.02$ & $5.20^{\mathrm{b}} \pm 0.01$ & $0.69^{\mathrm{b}} \pm 0.10$ \\
\hline T-2 & $14.67^{\mathrm{cd}^{\mathrm{d}}} \pm 0.01$ & $49.20^{\mathrm{b}} \pm 0.02^{\mathrm{b}}$ & $9.37^{\mathrm{a}} \pm 0.01$ & $5.25^{\mathrm{bc}} \pm 0.01$ & $0.76^{\mathrm{c}} \pm 0.10$ \\
\hline T-3 & $14.62^{\mathrm{c}} \pm 0.04$ & $49.70^{\mathrm{c}} \pm 0.01^{\mathrm{c}}$ & $9.44^{\mathrm{c}} \pm 0.01$ & $5.26^{\mathrm{bc}} \pm 0.02$ & $0.82^{\mathrm{d}} \pm 0.01$ \\
\hline T-4 & $14.58^{\mathrm{b}} \pm 0.01$ & $50.10^{\mathrm{d}} \pm 0.01^{\mathrm{d}}$ & $9.43^{\mathrm{c}} \pm 0.02$ & $5.30^{\mathrm{bc}_{1}} \pm 0.01$ & $0.75^{\mathrm{c}} \pm 0.01$ \\
\hline T-5 & $14.53^{\mathrm{a}} \pm 0.01$ & $50.40^{\mathrm{e}} \pm 0.01^{\mathrm{e}}$ & $9.39^{\mathrm{b}} \pm 0.11$ & $5.37^{\mathrm{c}} \pm 0.04$ & $0.82^{\mathrm{d}} \pm 0.01$ \\
\hline
\end{tabular}

Key a-e: Means with the same superscripts within each row are not significantly different $(\mathrm{p} \geq 0.05)$.

\section{Chemical composition of biscuit samples}

The proximate composition of biscuit samples is as shown in Table 4 . The moisture content range was within 3.22-4.58\%. Sample T-0 has the highest percentage moisture content of $4.98 \%$ while the least value was recorded for sample T-5 with of value of $3.22 \%$. The observed decrease in moisture content of biscuit samples as the level of substitution of chicken egg with duck egg increased could be explained by the fact that duck egg contains less moisture than chicken egg [19]. Moisture is a favourable sensorial attribute in baked products because it is synonymous with a soft, tender product though values higher than $10 \%$ promote microbial growth [25]. The protein content of the biscuit samples ranged from 9.4-12.9\%. Increase in the levels of duck egg substitution of chicken egg resulted in an increase in the protein content progressively, which is attributed to the high protein content of the duck egg. Substitution of $50 \%$ duck egg to chicken egg resulted in the highest protein content of $12.9 \%$. The large size of duck egg gives it a larger yoke to white ratio than chicken egg. Both egg white and egg yolk in the duck egg contains 3\% of more those amino acids than egg yolk and white of the hen egg. Duck egg white contains by about 50\% phenylalanine, about 30\% methionine and by about $24 \%$ threonine more than that of the hen egg. Similarly, duck egg yolk protein contains by $22 \%$ methionine and by $13 \%$ lysine more than that of the hen egg [26]. The result implies that the biscuit samples containing duck egg were high in protein content and could be used as alternative protein source in areas with protein deficiency.

Table 4. Proximate composition of biscuit samples

\begin{tabular}{|c|c|c|c|c|c|c|c|}
\hline Sample & $\begin{array}{l}\text { Moisture } \\
(\%) \\
\end{array}$ & \begin{tabular}{|l|} 
Protein \\
$(\%)$
\end{tabular} & $\begin{array}{l}\text { Fat } \\
(\%)\end{array}$ & $\begin{array}{l}\text { Ash } \\
(\%)\end{array}$ & $\begin{array}{l}\text { Fibre } \\
(\%)\end{array}$ & $\begin{array}{l}\text { Carbo- } \\
\text { hydrate (\%) }\end{array}$ & $\begin{array}{l}\text { Energy } \\
(\mathrm{kcal} / \mathrm{g})\end{array}$ \\
\hline T-0 & $4.78^{\mathrm{e}} \pm 0.03$ & & & & $0.51^{\mathrm{a}} \pm 0.01$ & & \\
\hline $\mathrm{T}-1$ & & & & & & & \\
\hline $\mathrm{T}-2$ & & & & & & & \\
\hline $\mathrm{T}-3$ & & $12.60^{\mathrm{d}} \pm 0.02$ & $17.96^{\mathrm{d}} \pm 0.03$ & $1.56^{\mathrm{d}} \pm 0.02$ & & & \\
\hline $\mathrm{T}-4$ & & & & & & & \\
\hline $\mathrm{T}-5$ & $3.22^{\mathrm{a}} \pm 0.03$ & $12.92^{\mathrm{f}} \pm 0.04$ & $19.18^{\mathrm{f}} \pm 0.03$ & $1.74^{\mathrm{ef}} \pm 0.03$ & $0.50^{\mathrm{a}} \pm 0.02$ & $62.44^{\mathrm{a}} \pm 0.06$ & $411.85^{f}$ \\
\hline
\end{tabular}

Key a-f: Means with the same superscripts within each row are not significantly different $(\mathrm{p} \geq 0.05)$ 
There was no significant difference $(\mathrm{p} \geq 0.05)$ in the fibre content of the samples. This is expected as chicken egg and duck egg contain virtually no fiber; hence the value reported was derived from other ingredients in biscuit formulation. The fat content of the biscuit samples ranged from 15.8$19.2 \%$. The fat content increases with higher levels of duck egg in the formulation. Duck egg contains higher yolk ratio to egg white, hence it has more fat and cholesterol than chicken egg [19]. More specifically, the yolk of an egg contains the cholesterol; the white contains none [28]. It has been reported that high levels of cholesterol in the bloodstream, especially low-density lipoprotein (LDL) cholesterol, are associated with increased risks of atherosclerosis and its consequences, including heart attacks and strokes [27]. However, cholesterol in the diet is not the principal factor affecting the level of cholesterol in the bloodstream. Previous extensive scientific research indicates that the type and amount of fat in the diet are more important in determining blood cholesterol levels than the amount of cholesterol in the diet [27]. The main dietary determinant of blood levels of LDL cholesterol is saturated fat intake [11]. Unlike many other foods that are high in cholesterol, such as fatty meats and full-fat dairy products, eggs are relatively low in saturated fat and calories. Cholesterol in the bloodstream comes from two sources: some are synthesized by the body, and some come from food. In most instances, when dietary cholesterol intake increases, the body compensates by decreasing its cholesterol production. Conversely, when cholesterol intake decreases, synthesis increases. The existence of this compensatory mechanism is the reason why changes in dietary cholesterol intake have only a limited effect on blood cholesterol levels. An analysis of data from a major United States national nutrition survey showed no relationship between dietary cholesterol intake and blood cholesterol level and actually found lower blood cholesterol levels in people who ate eggs frequently than in non-consumers [28].

There was a significant difference $(\mathrm{p} \leq 0.05)$ in the ash content of the biscuit samples. In case of biscuit samples containing duck egg, there was increase in ash content with increase in level of substitution. The carbohydrate content of biscuit samples varied from $62.4 \%$ to $68.8 \%$. Carbohydrate content of the control (T-0) was highest while sample T-5 had the lowest. The result implies that the biscuits are potential source of carbohydrate. Gross energy content ranged from $397.67 \mathrm{kcal} / \mathrm{g}$ to $411.85 \mathrm{kcal} / \mathrm{g}$ in the biscuits samples. The energy values indicate that the biscuits could serve as a good source of energy for the body.

\section{Mineral composition of biscuit samples}

Table 5 shows the amounts of mineral elements in biscuit samples. The results indicated the range of calcium, magnesium, potassium, phosphorus, iron and zinc to be $1.23-2.22 \mathrm{mg} / \mathrm{kg}, 2.99$ $5.50 \mathrm{mg} / \mathrm{kg}, \quad 8.01-12.60 \mathrm{mg} / \mathrm{kg}, 15.20-21.62 \mathrm{mg} / \mathrm{kg}$ and $0.31-0.58 \mathrm{mg} / \mathrm{kg}$ and $0.18-0.36 \mathrm{mg} / \mathrm{kg}$, respectively. Considering the concentrations of essential major and trace elements, nutrition of the biscuit samples was positive. It was observed that the concentration of mineral elements in biscuit samples containing different level of duck egg was higher than of the control, which is coincidental with the results of ash. The increase in mineral content in the biscuit samples as the level of substitution of chicken egg with duck egg increases could be due to higher concentrations in duck egg compare to chicken egg [19]. Duck egg is an excellent source of minerals such calcium, magnesium, phosphorus and potassium mostly found in the yolk. These macro elements are important in the diet because of their various functions in the body. In addition, iron and zinc concentrations were significantly higher in biscuit samples containing different levels of duck egg compared to the control. The iron in egg yolks, like the iron in meat, is highly bioavailable; egg yolks may, therefore, be valuable in the diets of individuals who may need more iron, such as infants [29]. Zinc is involved in well over one hundred different reactions in the body. Some of these reactions help the bodies construct and maintain DNA, and repair of tissues [30]. It is expected that slight enrichment of zinc as a result of substitution of chicken egg with duck egg in biscuit production would contribute to the reduction of diarrhea and pneumonia mortality in children. However, it is worthy to note that the concentration of these elements in all the blends is quite low though the optimum dietary level for the individual elements required for humans is very difficult to clarify because of each variation of physiological response. 
Table 5. Mineral composition of biscuit samples $(\mathrm{mg} / \mathrm{kg})$

\begin{tabular}{|c|c|c|c|c|c|c|}
\hline Sample & Calcium & Potassium & Magnesium & Phosphorus & Iron & Zinc \\
\hline T-0 & $1.23^{\mathrm{a}} \pm 0.01$ & $8.01^{\mathrm{a}} \pm 0.13$ & $2.99^{\mathrm{a}} \pm 0.05$ & $11.20^{\mathrm{a}} \pm 0.05$ & $0.31^{\mathrm{a}} \pm 0.01$ & $0.18^{\mathrm{a}} \pm 0.01$ \\
\hline $\mathrm{T}-1$ & $1.57^{b} \pm 0.02$ & $9.80^{\mathrm{b}} \pm 0.05$ & $3.40^{\mathrm{b}} \pm 0.01$ & $17.29^{b} \pm 0.03$ & $0.35^{b} \pm 0.01$ & $0.24^{b} \pm 0.01$ \\
\hline $\mathrm{T}-2$ & $1.72^{\mathrm{c}} \pm 0.03$ & $12.03^{c} \pm 0.04$ & $3.48^{\mathrm{bc}} \pm 0.01$ & $17.50^{\mathrm{c}} \pm 0.02$ & $0.40^{c} \pm 0.01$ & $0.27^{b c} \pm 0.01$ \\
\hline $\mathrm{T}-3$ & $1.89^{\mathrm{e}} \pm 0.01$ & $12.23^{\mathrm{d}} \pm 0.03$ & $3.86^{\mathrm{d}} \pm 0.03$ & $20.03^{\mathrm{d}_{ \pm}} \pm 0.02$ & $0.46^{\mathrm{d}} \pm 0.01$ & $0.32^{\mathrm{c}} \pm 0.01$ \\
\hline $\mathrm{T}-4$ & $1.85^{\mathrm{d}} \pm 0.02$ & $12.25^{\mathrm{de}} \pm 0.01$ & $4.46^{\mathrm{e}} \pm 0.01$ & $20.64^{\mathrm{e}} \pm 0.11$ & $0.51^{\mathrm{e}} \pm 0.01$ & $0.27^{\mathrm{bc}} \pm 0.01$ \\
\hline $\mathrm{T}-5$ & $2.22^{\mathrm{f}} \pm 0.01$ & $12.60^{f} \pm 0.02$ & $5.50^{\mathrm{f}} \pm 0.02$ & $21.32^{\mathrm{f}} \pm 0.03$ & $0.58^{\mathrm{f}} \pm 0.02$ & $0.36^{\mathrm{d}} \pm 0.01$ \\
\hline
\end{tabular}

Key a-f: Means with the same superscripts within each row are not significantly different $(\mathrm{p} \geq 0.05)$

\section{Sensory quality of biscuit samples}

Mean score for sensory evaluation of biscuit given in Fig. 1. The result revealed significant differences $(\mathrm{p} \leq 0.05)$ between treatments for sensory attributes like colour, taste, flavour, crunchiness, texture, sweetness and overall acceptability. Sensory rating of biscuit for colour shows that sample T-0 was rated highest (4.75) while sample T-1 was rated lowest (4.00). Colour is a very important parameter in judging properly baked biscuits that not only reflect the suitable raw material used for the preparation but also provides information about the formulation and quality of the product [31]. Darker colour was noted in biscuit samples containing varying level of chicken egg and duck egg compared to the control (sample T-0). The change in colour may be due to the non-enzymatic reaction between reducing sugar molecules and higher level of protein in duck egg. In the taste attribute, the result showed that the biscuit sample containing 50\% duck egg had the highest mean score of 4.55 . This was closely followed by that of $40 \%$ and $20 \%$ substitutions with duck egg with mean scores of 4.30 and 4.25 respectively. Duck egg has much larger yolk than chicken egg and consequently much higher fat content which gives a rich taste to biscuits. In terms of flavour, there was no significant difference $(p \geq 0.05)$ among the samples. The observation is in accordance with the finding of Niewiarowicz et al. [32] that revealed no flavour differences between hard-boiled Peking duck and "Astra S" hen eggs.

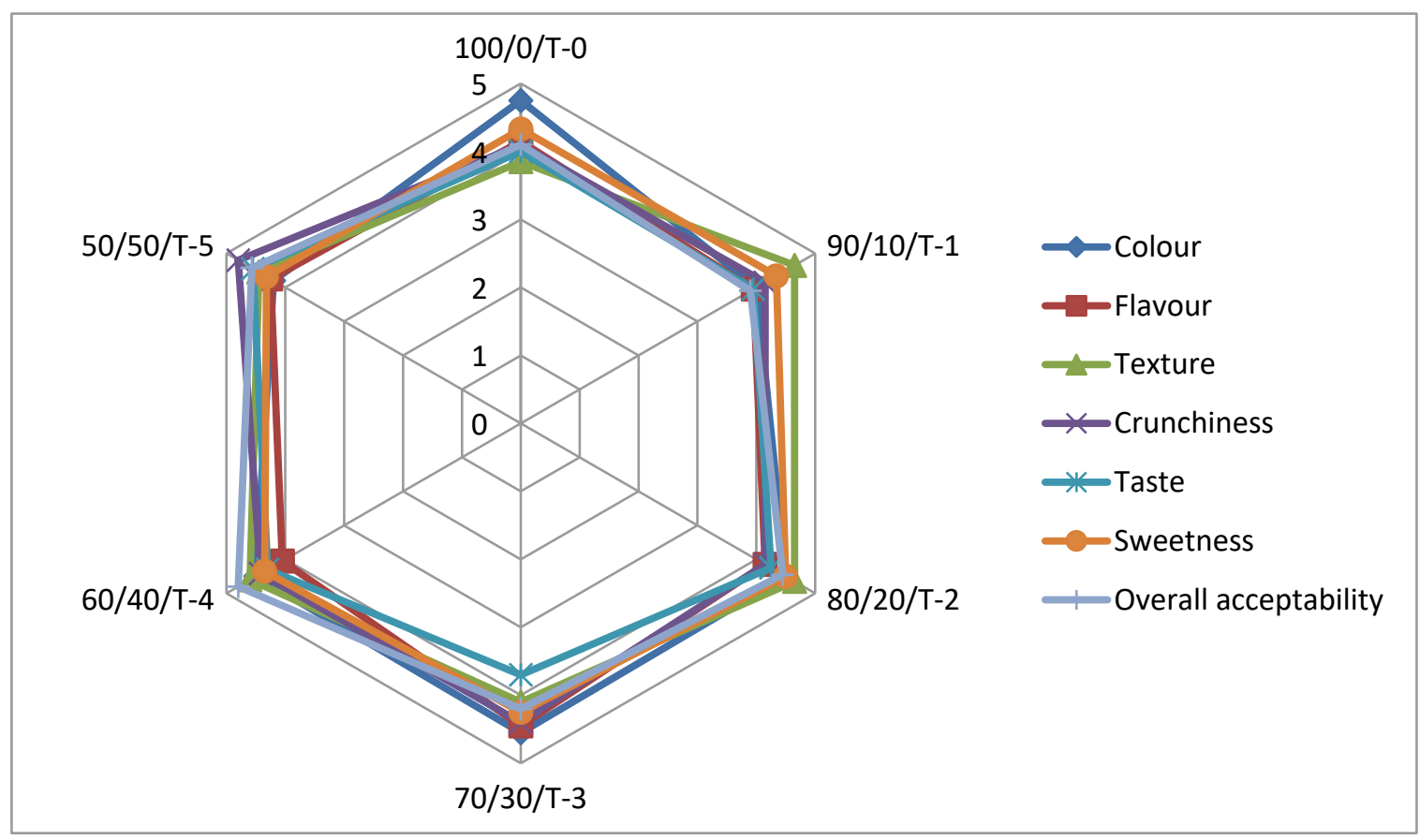

Figure 1. Sensory mean scores of biscuit samples containing varying levels of duck egg

Egg yolk is rich in fat and lecithin and these components enhance the flavour and eating quality of biscuit. Panellists accepted the crunchiness of the biscuit samples up to $50 \%$ substitution with a mean value of 5.84. From the result, the crispness of the biscuits increased with increase in the level of duck egg in the formulation. Considering the texture of the biscuits, samples containing different levels of duck egg were highly rated compared to the control. Duck egg impacts a creamier, richer 
texture to biscuits due to the higher fat content. Fats also tend to inhibit the leaving action of carbondioxide diffusion in the dough during baking which subsequently results in product with a softer texture. Moreover, this expresses the ability of more egg white in duck egg which helps incorporate air in dough during mixing that affects the textural properties [33]. In terms of sweetness, there was no significant difference $(p \geq 0.05)$ among the samples. However, the overall acceptability of biscuits containing different levels of duck eggs was rated higher than that of the control.

Generally, the observed differences in consumer's preference and overall acceptability of the biscuit samples could be explained by the variation in the physical, chemical properties of ingredients in the various formulations. It is worthy to note that in the baking industry in particular, eggs supply unique and extensive concentration of functional contributions which is not likely to be exhibited in egg substitute as an ingredient. Eggs contribute high nutritional value and multifunctional properties that make researchers to often admit that the use of egg replacer is not a match to egg in terms of product quality.

\section{Conclusions}

This present study shows that there is potential for different combinations of duck egg to replace chicken egg in biscuit production. Substitution of duck egg induces major changes in the physical properties of the biscuits. Similarly, biscuit samples of adequate nutritional and sensorial qualities were produced from the blends. The substitution of chicken egg with duck egg at a level of up to $40 \%$ produces biscuit without any negative effects in quality attributes and reasonable acceptance, offering a promising, nutritious and healthy alternative to consumers.

\section{Acknowledgement}

The authors sincerely acknowledge the support of the staff of Food Science and Technology, Bowen University, Osun State, Nigeria.

\section{Conflict of Interest}

The authors declare that there is no conflict of interest.

\section{References}

[1] O.A. Olaoye, A.A. Onilude, C.O. Oladoye, Breadfruit flour in biscuit making, African Journal of Food Science. (2007) 20-23.

[2] S.D. Kulkarni, Roasted soybean in cookies: Influence on product Quality, J. Food Sci. Technol. 34 (1997) 503-505.

[3] P. Wade, Biscuits, Cookies and Crackers: The Principle of the Craft. Elsevier Applied Science, London, 1988.

[4] E. Applegate, Introduction: nutritional and functional roles of eggs in the diet, Journal of the American College of Nutrition. 19 (2000) 495S-498S.

[5] R.S. Bird, The future of modern duck production, breeds and husbandry in Southeast Asia. In: First INFPD/FAO Electronic Conference on Family Poultry. 1986. Available: http://LPA/Fampol/freecom4.htm. Accessed: 8/10/18.

[6] Z. Yan et al., Physicochemical and nutritional characteristics of preserved duck egg white. Poultry Science. 93(2008) 3130-3137.

[7] P. Lehman, Duck egg benefits defined, Nutritional benefits of duck egg. 2016. Available: http://www.swissvillallc.com/. Accessed: 8/10/17. 
[8] S.R. Smith, P.A. Martin, R.H.T. Edwards, Tumour $\mathrm{pH}$ and response to chemotherapy: an in vivo $31 \mathrm{P}$ magnetic resonance spectroscopy study in non-Hodgkin's lymphoma, British Journal of Radiology. 64(766) (1991) 923-928.

[9] P. Pietinen et al., Intake of fatty acids and risk of coronary heart disease in a cohort of Finnish men. The Alpha-Tocopherol, Beta-Carotene Cancer Prevention Study, American Journal of Epidemiology. 145 (1997) 876-877.

[10] F.B. Hu et al., A prospective study of egg consumption and risk of cardiovascular disease in men and women, Journal of the American Medical Association. 281(1999) 1387-1394.

[11] American Heart Association (AHA), AHA dietary guidelines. A statement for healthcare professionals from the nutrition committee of the American Heart Association, Circulation. 102 (2000) 2296-2311.

[12] O.O. Onabanjo, Nutritional, functional and sensory properties of biscuit produced from wheatsweet potato composite, Journal of Food Technology Research. 1(3) (2014) 111-121.

[13] American Association of Cereal Chemists (AACC). 2000. Approved Methods of Analysis. The American Association of Cereal Chemists. St. Paul, Minnesota.

[14] J.C. Okaka, N.N. Potter, Functional properties of cowpea wheat flour blends in bread making, Journal of Food Science. 42 (1997) 828-833.

[15] Association of Official Analytical Chemists (AOAC). 2012. Official methods of analysis, 19th Ed. AOAC International, Suite 500, 481 North Frederick Avenue, Gaithersburg, Maryland.

[16] S. Ekanayake, E.R. Jans, B.M. Nair, Proximate composition, mineral and amino acid content of mature Canavalia gladiata seeds, Food Chemistry. 66 (1999) 115-119.

[17] Association of Official Analytical Chemists (AOAC), Official methods of analysis, 18th Ed. Maryland, USA, 2005.

[18] G.I. Onwuka, Food Analysis and Instrumentation. Theory and Practice. Naphtali Prints, Lagos, Nigeria, 2005.

[19] J. Pikul, Characteristics of duck eggs and the quality of duck eggs products, Arch. Geflügelk. 62 (2) (1998) 72-82.

[20] B. Jamilah et al., Physico-chemical characteristics of red pitaya (Hylocereus polyrhizus) peel, International Food Research Journal. 18 (2011) 279-286.

[21] K.O. Ajanaku et al., Nutritive value of sorghum ogi fortified with groundnut seed (Arachis hypogaea L.), American Journal of Food Technology. 7 (2012) 372-379.

[22] J.R. Priestly, Effect of Heating on Foodstuffs. National Food Research Institute Pretoria, South Africa Applied Science Publishers Ltd. London, 1979, pp. 72-73.

[23] J.A. Ayo, I. Nkama, Effect of acha (Digitaria exilis Staph) grain flours on the physical and sensory quality of biscuit, Nutrition and Food Science. 33 (2003) 125-130.

[24] R.C. Hoseney, D.E. Rogers, Mechanism of sugar functionality in cookies, in: H. Faridi (Ed.), The Science of Cookie and Cracker Production, New York, 1994, pp. 203-226.

[25] E. Julianti, H. Rusmarilin, E. Yusraini, Functional and rheological properties of composite flour from sweet potato, maize, soybean and xanthan gum, Journal of the Saudi Society of Agricultural Sciences. 16 (2015) 171-177.

[26] A. Niewiarowicz, Food Industry, Przemysl Spoziywczy. 45 (1991) 103-113.

[27] American Council on Science and Health (ACSH). 2002. Facts about "Functional Foods". Available: http://www.acsh.org/publications/booklets/funfood2002.pdf. Accessed: 8/10/17. 
[28] W.O. Song, J.M. Kerver, Nutritional contributions of eggs to American diets, J. Am. Coll. Nutr.19 (2000) 556S-562S.

[29] M. Makrides et al., Nutritional effect of including egg yolk in the weaning diet of breast-fed and formula-fed infants: a randomized controlled trial, Am. J. Clin. Nutr. 75 (2002) 1084-1092.

[30] C. Debjit Bhowmik, K.P. Sampath Kumar, A potential medicinal importance of zinc in human health and chronic disease, International Journal Pharmaceutical and Biomedical Sciences. 1(1) (2010) 5-11.

[31] M. Ferial, A. Abu-Salem, A. Abou-Arab, Effect of supplementation of bambara groundnut (Vigna subterranean L.) flour on the quality of biscuits, African Journal of Food Science. 5(7) (2011) 376-383.

[32] A. Niewiarowicz et al., Project CPBR 6.P.0.4. Part III. Poultry Research Center, Poznaii, 1989, pp. 1-25.

[33] K. Kubomura, Instant noodles in Japan, Cereal Foods World. 43 (1998) 194-197. 